References

${ }^{1}$ Rosenbaum, F. F., and Levine, S. A., Archives of Internal Medicine, 1941, 68, 913.

2 Peel, A. A. F., et al., British Heart fournal, 1962, 24, 745.

3 Gazes, P. C., Richardson, J. A., and Woods, E. F., Circulation, 1959, 19, 657.

4 Siggers, D. C., Salter, C., and Fluck, D. C., British Heart fournal, 1971, 33, 878 .

5 World Health Organization, Hypertension and Coronary Heart Disease, Technical Report Series No. 168. Geneva, W.H.O., 1959.

6 Perloff, J. K., Circulation, 1964, 30, 706.

${ }^{7}$ Marrott, P., et al., British Heart fournal, 1973, 12, 1240.

${ }^{8}$ Maroko, P. R., et al., Circulation, 1971, 43, 67.
${ }^{9}$ Maroko, P. R., and Braunwald, E., Annals of Internal Medicine, 1973, 79, 720.

10 Shell, W. E., and Sobel, B. E., New England fournal of Medicine, 1974, $291,481$.

11 Lemley-Stone, J., et al., American fournal of Physiology, 1955, 183, 555.

12 Nydick, I., Wroblewski, F., and LaDue, J. S., Circulation, 1955, 12, 161.

13 Jewitt, D. E., et al., Lancet, 1969, 1, 635.

14 Sobel, B. E., and Shell, W. E., Circulation, 1973, 47, 215.

15 Mueller, H. S., et al., Circulation, 1974, 49, 1078.

${ }^{16}$ Hirshfield, J. W. et al., Circulation, 1974, 49, 291.

17 Ginks, W. R., et al., fournal of Clinical Investigation, 1972, 51, 2717.

18 Maroko, P. R., et al., Circulation, 1972, 45, 1150.

19 Messer, J. V., et al., Clinical Research, 1973, 21, 438.

20 Kelly, D. T., et al., Circulation, 1973, 47, 729.

\title{
Use of Clomiphene and Luteinizing Hormone/Follicle Stimulating Hormone-releasing Hormone in Investigation of Ovulatory Failure
}

\author{
JEAN GINSBURG， A. J. ISAACS， MARION B. R. GORE， C. W. H. HAVARD
}

British Medical fournal, 1975, 3, 130-133

\section{Summary}

A luteinizing hormone/follicle-stimulating hormonereleasing hormone (LH/FSH-RH) test was performed in 70 women with amenorrhoea or anovulatory infertility, or both, and a clomiphene stimulation test was also performed in 24 of these patients. Most patients responded to LH/FSH-RH with significant increases in LH and FSH. In women with gonadal dysgenesis or premature ovarian failure exaggerated responses were observed after LH/FSH-RH and there was no change in high basal LH levels after clomiphene. Patients with absent or impaired responses to LH/FSH-RH failed to respond to clomiphene. All patients with anovulatory menstrual cycles responded to both LH/FSH-RH and clomiphene, while seven out of 13 amenorrhoeic patients with a normal LH/FSH-RH response showed an early LH rise during clomiphene treatment and six were unresponsive. These results suggest a difference between the two groups at hypothalamic level with consequent therapeutic implications.

\section{Introduction}

The synthetic decapeptide luteinizing hormone/follicle-stimulating hormone-releasing hormone (LH/FSH-RH) stimulates luteinizing hormone $(\mathrm{LH})$ and follicle-stimulating hormone (FSH) release in man, ${ }^{1}$ but a $\mathrm{LH} / \mathrm{FSH}-\mathrm{RH}$ test alone cannot distinguish between hypothalamic and pituitary causes of hypogonadism. ${ }^{2}$ Since clomiphene citrate also induces a rise in gonadotrophin levels, ${ }^{3}{ }^{4}$ an effect presumed to be mediated via endogenous $\mathrm{LH} / \mathrm{FSH}-\mathrm{RH}$, a study was undertaken to determine whether by the use of both LH/FSH-RH and clomiphene

\footnotetext{
Departments of Endocrinology, Gynaecology, and Chemical Pathology, Royal Free Hospital, London NW3 2QG

JEAN GINSBURG, D.M., M.R.C.P., Consultant Endocrinologist A. J. ISAACS, B.M., M.R.C.P., Abbott Research Fellow MARION B. R. GORE, B.SC., PH.D., Principal Biochemist

C. W. H. HAVARD, D.M., F.R.C.P., Consultant Physician and Endocrinologist
}

citrate the site of dysfunction in patients with disturbed hypothalamo-pituitary-gonadal function might be established with more precision, thereby facilitating the selection of appropriate treatment.

We report here the effects of giving clomiphene to 24 out of 70 anovulatory women who had had a LH/FSH-RH test.

\section{Patients}

Seventy patients presenting with amenorrhoea (56 women aged 17-42 years) or anovulatory cycles (14 women aged 24-38 years) were studied. The cause of amenorrhoea or anovulation was investigated fully in each case; gynaecography was performed in 30 and laparoscopy in 34 women.

Twenty women had primary amenorrhoea. Gonadal dysgenesis confirmed by gynaecography or laparoscopy was present in five of these, two of whom showed chromosomal abnormalities. Laparoscopy in seven of the remaining 15 patients showed small ovaries but biopsy showed plentiful follicular tissue in five women.

Of the other 36 amenorrhoeic patients six presented with menopausal symptoms suggesting premature ovarian failure; no follicles were seen in ovarian biopsies from four, and in the other two, though occasional follicles were observed, there was no change in urinary oestrogen levels after large doses of human menopausal gonadotrophins. Amenorrhoea occurred after stopping oral contraception in seven women, after a miscarriage in one, and after delivery in one. The onset of amenorrhoea was associated with weight loss in 11 women, five of whom were considered to have anorexia nervosa; emotional factors were implicated in four other women. One woman had chronic liver disease with sclerocystic ovaries found at laparoscopy, and one suffered from intestinal malabsorption. No clear cause was apparent in the remaining four women. Of the 14 women with anovulatory cycles six had sclerocystic ovaries shown by laparoscopy or gynaecography.

LH/FSH-RH tests were performed in all 70 women and also in seven healthy women with regular menses; six of the latter were parous and all were studied in the follicular phase. Clomiphene stimulation tests were performed in 24 patients (seven with primary amenorrhoea, 12 with secondary amenorrhoea, and five with anovulatory cycles, see table).

\section{Methods}

LH/FSH-RH Test.-LH/FSH-RH (Hoechst) $100 \mu \mathrm{g}$ was given by rapid intravenous injection and venous blood samples taken at 0 , 20 , and 60 minutes. ${ }^{5}$

Clomiphene Stimulation Test.-Clomiphene citrate $\left(2 \mathrm{mg} \mathrm{kg}^{-1}\right.$ day $^{-1}$ to the nearest $50 \mathrm{mg}$ ) was given by mouth for seven days, starting on 
the third day of the cycle in those who were menstruating. Blood samples were taken every two or three days for 11 days and then daily until day 19. Twenty-four hour urinary collections for pregnanediol estimation were made before starting clomiphene and after three weeks.

Serum LH and FSH were measured in duplicate by double antibody radioimmunoassay, ${ }^{5}$ using $\mathrm{LH}$ standard M.R.C. 68/40 (77 units per ampoule) and FSH standard M.R.C. 69/104 (10 units per ampoule). Iodination material and anti-LH serum were obtained from the M.R.C. Division of Biological Standards. Anti-FSH serum was provided by Professor Butt, Birmingham. Serum was stored at $-20^{\circ} \mathrm{C}$ and all samples from each individual assayed in the same batch. Urinary pregnanediol was assayed as the diacetate derivative by gas-liquid chromatography. ${ }^{6}$

\section{Results}

LH/FSH-RH TEST

Healthy Subjects.-LH levels increased considerably at 20 minutes with lower 60-minute levels (fig. 1). Basal FSH levels were much lower with a similar percentage increase at 20 minutes, but no drop at 60 minutes.

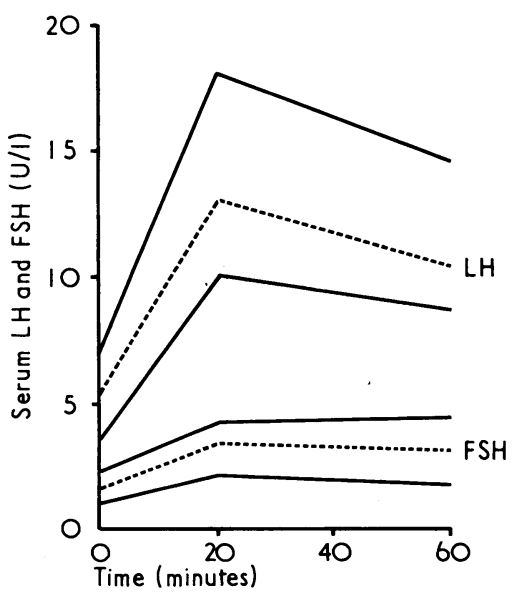

FIG. 1-Serum LH and FSH in seven healthy women with regular menses after $\mathrm{LH} / \mathrm{FSH}-\mathrm{RH} 100 \mu \mathrm{g}$ given intravenously at time 0 . Mean values indicated by interrupted lines, range by solid lines.

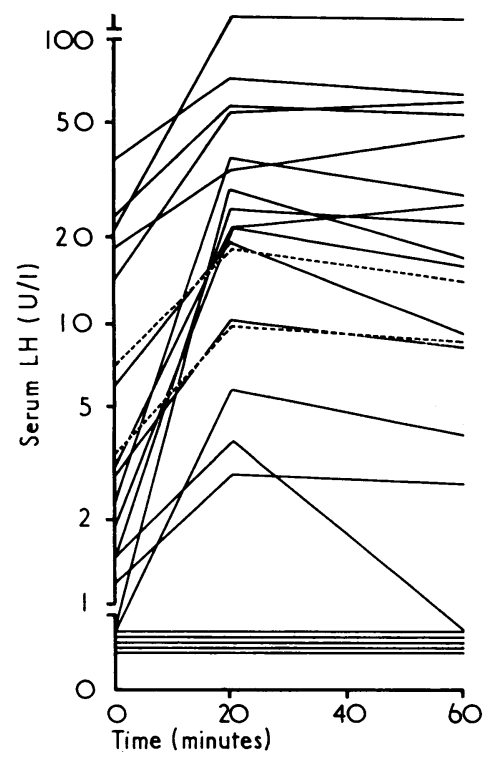

FIG. 2-Serum LH in 20 patients with primary amenorrhoea after LH/FSH-RH $100 \mu \mathrm{g}$ given intravenously at time 0 . Dotted lines indicate normal response. Note logarithmic scale.
Women with Primary Amenorrhoea.-Basal serum LH and FSH levels were considerably raised in the five women with gonadal dysgenesis (figs. 2 and 3). LH/FSH-RH evoked a further large rise in LH and in three cases also in FSH but with no fall at 60 minutes.

In only one of the other 15 patients did both $\mathrm{LH}$ and $\mathrm{FSH}$ respond normally. Basal serum LH was below normal or undetectable in 12 and $\mathrm{FSH}$ in 11. $\mathrm{LH}$ release significantly exceeded control levels in five cases, was impaired in three, and absent in five (fig. 2). FSH release exceeded control values in five and was absent in five cases (fig. 3).

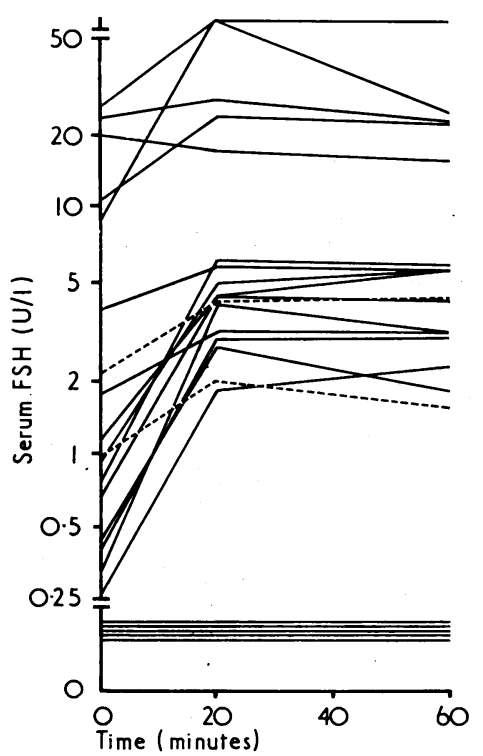

FIG. 3-Serum FSH in 20 patients with primary amenorrhoea after LH/FSH-RH $100 \mu \mathrm{g}$ given intravenously at time 0 . Dotted lines indicate normal response. Note logarithmic scale.

Women with Secondary Amenorrhoea.-Release of both gonadotrophins was observed after $\mathrm{LH} / \mathrm{FSH}-\mathrm{RH}$ in all except one woman. In the six women with a premature menopause basal levels of LH and FSH were raised and the results after $\mathrm{LH} / \mathrm{FSH}-\mathrm{RH}$ were similar to those in patients with gonadal dysgenesis. The remaining 30 patients fell into those with normal or raised basal LH levels (3-16.5 U/1) and those with low basal $\mathrm{LH}$ levels $(\leqslant 2 \mathrm{U} / \mathrm{l})$. In the former group (12 patients) mean values were $9 \cdot 0,38$, and $31 \mathrm{U} / 1$ at 0,20 , and 60 minutes respectively. FSH also rose sharply but with a smaller drop at 60 minutes, the mean values being $1.9,6.7$, and $6.0 \mathrm{U} / 1$ respectively. In the group with low basal LH levels (18 patients) LH responses exceeded control responses in six patients, were similar to them in six, and were diminished in six. FSH responses tended to be similar to or exceeded those of the controls. One patient with anorexia nervosa showed no change in either LH or FSH after LH/FSH-RH.

Women with Anovulatory Cycles.-In only one of the women with sclerocystic ovaries was the response to LH/FSH-RH subnormal and then only in respect of FSH. The other patients showed normal to excessive LH and FSH release.

\section{CLOMIPHENE TEST}

The normal $\mathrm{LH}$ response to clomiphene during an ovulatory cycle consists of an increase in LH during administration of clom:iphene and a subsequent fall before a second preovulatory LH peak."

Women with Primary Amenorrhoea.-Six women bid low or undetectable LH levels initially. Though four showed a r:ositive response to $\mathrm{LH} / \mathrm{FSH}-\mathrm{RH}$ in only one did $\mathrm{LH}$ increase dicing clomiphene administration; subsequently $\mathrm{LH}$ fell and there wes no rise in pregnanediol and no menstruation. The other three patients were unresponsive to clomiphene with undetectable LH levels throughout the test, as were one patient with an impaired and one with an absent LH/FSH-RH response. None of these patients showed a rise in pregnanediol and none menstruated. One patient with gonadal dysgenesis maintained raised $\mathrm{LH}$ levels throughout the clomiphene 
Clinical Details and Gonadotrophin Levels in 24 Patients who Underwent Clomiphene Stimulation Iests

\begin{tabular}{|c|c|c|c|c|c|c|c|c|c|}
\hline \multirow{3}{*}{$\begin{array}{l}\text { Case } \\
\text { No. }\end{array}$} & \multirow{3}{*}{$\begin{array}{l}\text { Development of Secondary } \\
\text { Sexual Characteristics in } \\
\text { Women with Primary } \\
\text { Amenorrhoea and Cause } \\
\text { of Secondary Amenorrhoea } \\
\text { or Anovulatory Cycles }\end{array}$} & \multirow{3}{*}{$\begin{array}{l}\text { Ovarian } \\
\text { Follicles }\end{array}$} & \multicolumn{4}{|c|}{ LH/FSH-RH Test } & \multirow{2}{*}{\multicolumn{3}{|c|}{$\begin{array}{c}\text { Clomiphene Test } \\
\mathrm{LH}(\mathrm{U} / \mathrm{l})\end{array}$}} \\
\hline & & & \multicolumn{2}{|c|}{$\mathrm{LH}(\mathrm{U} / \mathrm{l})$} & \multicolumn{2}{|c|}{$\mathrm{FSH}(\mathrm{U} / \mathrm{l})$} & & & \\
\hline & & & Basal & Maximum & Basal & Maximum & Basal & Early Rise & Peak \\
\hline $\begin{array}{l}1 \\
2 \\
3 \\
4 \\
5 \\
6 \\
7\end{array}$ & $\begin{array}{l}\text { Poor } \\
\text { Good* } \\
\text { Good* } \\
\text { Good } \\
\text { Poor } \\
\text { Poor } \\
\text { Absent } \\
\text { (thalassaemia major) }\end{array}$ & $\begin{array}{l}\text { Streak ovaries } \\
\text { Plentiful } \\
\text { Moderate } \\
\text { Scanty } \\
\text { Scanty } \\
\text { Plentiful } \\
\text { No biopsy }\end{array}$ & $\begin{array}{l}n \text { with } \\
14 \cdot 5 \\
3 \\
<1 \\
2 \\
1 \cdot 5 \\
<1 \\
<1\end{array}$ & $\begin{array}{l}\text { ary Amenorrh } \\
61 \\
27 \\
29 \\
23 \\
25 \\
6 \\
<1\end{array}$ & $\begin{array}{c}10.5 \\
1.1 \\
0.9 \\
0.3 \\
0.7 \\
0.4 \\
<0.25\end{array}$ & $\begin{array}{c}24 \\
5 \cdot 7 \\
5 \cdot 6 \\
4 \cdot 0 \\
6 \cdot 1 \\
2 \cdot 7 \\
<0 \cdot 25\end{array}$ & $\begin{array}{l}14 \cdot 3 \\
3 \\
<1 \\
<1 \\
<1 \\
<1 \cdot 2\end{array}$ & $6 \cdot 5$ & \\
\hline $\begin{array}{r}8 \\
9 \\
10 \\
11 \\
12 \\
13 \\
14 \\
15 \\
16 \\
17 \\
18 \\
19\end{array}$ & $\begin{array}{l}\text { Premature menopause } \\
\text { Premature menopause } \\
\text { After oral contraceptives } \\
\text { None apparent } \\
\text { Weight loss } \\
\text { Weight loss } \\
\text { Weight loss } \\
\text { Weight loss } \\
\text { Anorexia nervosa } \\
\text { Weight loss } \\
\text { Weight loss } \\
\text { Emotional factors }\end{array}$ & $\begin{array}{l}\text { Scanty } \\
\text { Moderate } \\
\text { Plentiful } \\
\text { Scanty } \\
\text { No biopsy } \\
\text { No biopsy } \\
\text { Absent } \\
\text { No biopsy } \\
\text { No biopsy } \\
\text { Scanty } \\
\text { No biopsy } \\
\text { No biopsy }\end{array}$ & $\begin{array}{l}\text { with } S \\
20 \\
31 \\
7 \\
2 \\
11 \cdot 5 \\
4 \\
1 \cdot 5 \\
<1 \\
2 \\
3 \\
<1 \\
<1\end{array}$ & $\begin{array}{l}\text { lary Amenorr } \\
57 \\
83 \\
45 \\
20 \\
24 \\
38 \\
12 \\
12 \cdot 5 \\
20 \\
15 \\
25 \\
3 \cdot 5\end{array}$ & $\begin{array}{l}25 \\
18 \\
1.0 \\
0.9 \\
3.7 \\
1 \\
0.5 \\
0.6 \\
0.9 \\
0.7 \\
0.8 \\
1.1\end{array}$ & $\begin{array}{l}37 \\
26 \\
6 \cdot 3 \\
7 \cdot 4 \\
5 \cdot 6 \\
5 \cdot 4 \\
3 \cdot 4 \\
2 \cdot 5 \\
5 \cdot 5 \\
2 \cdot 8 \\
5 \cdot 3 \\
2 \cdot 1\end{array}$ & $\begin{array}{c}21 \\
24 \\
2 \cdot 1 \\
6 \cdot 7 \\
2 \\
<1 \\
<1 \\
2 \cdot 5 \\
1 \cdot 9 \\
3 \cdot 3 \\
<1 \\
<1\end{array}$ & $\begin{array}{c}10 \cdot 8 \\
11.5 \\
11.9 \\
10 \\
8.5 \\
<1 \\
6.6\end{array}$ & $\begin{array}{l}49 \\
39\end{array}$ \\
\hline $\begin{array}{l}20 \\
21 \\
22 \\
23 \\
24\end{array}$ & $\begin{array}{l}\text { None apparent } \\
\text { Sclerocystic ovaries } \\
\text { Sclerocystic ovaries } \\
\text { Sclerocystic ovaries } \\
\text { Sclerocystic ovaries }\end{array}$ & $\begin{array}{l}\text { Moderate } \\
\text { Moderate } \\
\text { Scanty } \\
\text { Moderate } \\
\text { Scanty }\end{array}$ & $\begin{array}{c}\text { nen with } \\
6 \cdot 5 \\
9 \cdot 5 \\
13 \cdot 5 \\
4 \\
6\end{array}$ & $\begin{array}{c}\text { vulatory Cyc } \\
28 \\
26 \\
41 \\
32 \\
44\end{array}$ & $\begin{array}{l}2.9 \\
1.7 \\
1.9 \\
0.8 \\
1.5\end{array}$ & $\begin{array}{l}4 \cdot 7 \\
4 \cdot 3 \\
3 \cdot 8 \\
3 \cdot 9 \\
5\end{array}$ & $\begin{array}{c}3 \cdot 3 \\
4 \cdot 2 \\
14 \cdot 3 \\
4 \\
7 \cdot 3\end{array}$ & $\begin{array}{r}17 \cdot 7 \\
9 \cdot 6 \\
26 \cdot 4 \\
8 \cdot 1 \\
17 \cdot 3\end{array}$ & 30 \\
\hline
\end{tabular}

*Patients in cases 2 and 3 had received oestrogen treatment, respectively, five and two years earlier.

test; there was no increase in pregnanediol excretion and no menstruation (see table).

Women with Secondary Amenorrhoea.-Two women showed the "normal ovulatory pattern" after clomiphene accompanied by a rise in pregnanediol excretion (fig. 4) and menstruated after the course. Four patients showed a similar early rise of $\mathrm{LH}$, but $\mathrm{LH}$ levels then fell with no evidence of a secondary peak and no rise in pregnanediol. Four women showed no early rise in LH and levels remained low throughout the test. The two patients with suspected premature ovarian failure had raised basal LH levels unaffected by clomiphene (see table).

Women with Anovulatory Cycles.-All five women showed an early LH rise on clomiphene treatment (see table). There was a subsequent rise to a peak in one case, a secondary rise though no clear LH peak in three, and a slow decline in LH levels after the early rise with no subsequent peak in one. Significant rises in urinary pregnanediol were observed in each case.

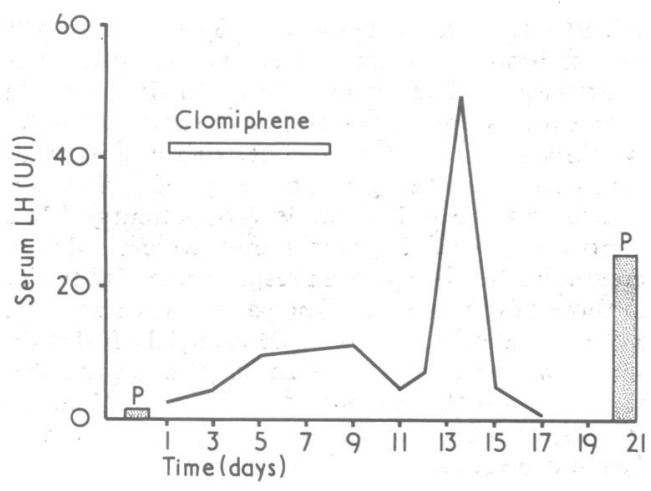

FIG. 4-Serum LH after clomiphene citrate ( $100 \mathrm{mg} /$ day) in woman with normal ovulatory response. $P=$ Urinary pregnanediol $(0.5 \mathrm{mg} / 24 \mathrm{~h}$ rising to $25 \mathrm{mg} / 24 \mathrm{~h})$.

\section{Discussion}

Our results showed that most of the women with anovulation could release adequate $\mathrm{LH}$ and $\mathrm{FSH}$ in response to $\mathrm{LH} / \mathrm{FSH}-$ $\mathrm{RH}$. In only three patients with primary amenorrhoea and one with secondary amenorrhoea and anorexia nervosa did both $\mathrm{LH}$ and FSH fail to respond to LH/FSH-RH.

Two patients with primary amenorrhoea, one of whom also suffered from anorexia nervosa, had absent LH but normal FSH responses. Three further patients with primary amenorrhoea and four with secondary amenorrhoea had impaired LH responses; of these two showed absent, four normal, and one an excessive FSH response. One patient with irregular periods and gynaecographic evidence of sclerocystic ovaries showed normal LH but grossly impaired FSH release. This heterogeneity of response to $\mathrm{LH} / \mathrm{FSH}-\mathrm{RH}$ confirms reports in, for example, "isolated gonadotrophin deficiency" 7 and anorexia nervosa. ${ }^{8}$

The other 56 patients, though anovulatory, showed gonadotrophin responses to $\mathrm{LH} / \mathrm{FSH}-\mathrm{RH}$ comparable to or greater than those of normal women. The response to clomiphene in 21 such patients was, however, variable. Three women with an exaggerated response to $\mathrm{LH} / \mathrm{FSH}-\mathrm{RH}$ and primary ovarian failure showed no response. Six patients with a normal response to $\mathrm{LH} / \mathrm{FSH}-\mathrm{RH}$ showed no $\mathrm{LH}$ response in relation to clomiphene and did not menstruate. A normal response to $\mathrm{LH} / \mathrm{FSH}-\mathrm{RH}$ does not therefore imply clomiphene responsiveness.

Clomiphene is thought to act essentially through competition with oestrogen at hypothalamic receptor sites, stimulating release of $\mathrm{LH} / \mathrm{FSH}-\mathrm{RH}$ and gonadotrophins by negative feedback. Thus, clomiphene's failure to evoke a response when there was a positive response to $\mathrm{LH} / \mathrm{FSH}-\mathrm{RH}$ suggests a functional defect at hypothalamic level or above. In some patients with primary amenorrhoea, previously considered to be due to "isolated gonadotrophin deficiency," the defect may be an absence of the releasing hormone itself. In other patients, such as those with anorexia nervosa, influences above the level of the hypothalamus may interfere with $\mathrm{LH} / \mathrm{FSH}-\mathrm{RH}$ production or release or both. Treatment of the underlying illness may reverse this situation and restore clomiphene responsiveness. ${ }^{9}$

Conversely, since the normal response to clomiphene ${ }^{34}$ depends on a functioning hypothalamo-pituitary-ovarian axis those patients with a normal response to clomiphene should also respond normally to LH/FSH-RH (as shown in our study), whereas failure to respond to LH/FSH-RH was associated with unresponsiveness to clomiphene.

Thus, though it has been claimed that the LH/I:SH-RH test alone is not helpful in distinguishing between pituitary and hypothalamic causes of hypogonadism ${ }^{2}$ it $\mathrm{i} ;$; possible, by performing both a clomiphene and a $\mathrm{LH} / \mathrm{F} ; \mathrm{H}-\mathrm{RH}$ test, to effect a functional separation which may be us.ful in treatment.

The clomiphene stimulation test presents certain practical difficulties: the preovulatory LH peak, for example, may be missed unless daily blood samples are taken. In our study, however, all patients with an early LH rise during clomiphene administration also showed a normal $\mathrm{LH}$ and $\mathrm{FSH}$ response to 
LH/FSH-RH. This rise usually started on the second or third day, reached a maximum between the seventh and 11th days, and could be monitored every two or three days. For clinical purposes we therefore suggest sampling on days, $1,3,5,8$, and 11 of clomiphene administration, an $\mathrm{LH}$ rise of at least $3.5 \mathrm{U} / 1$ to a maximum above $6 \mathrm{U} / 1$ over this period indicating the integrity of the hypothalamo-pituitary-ovarian axis. Pregnanediol or other indirect indices of ovulation may be monitored also, but this is not essential.

The LH/FSH-RH test is thus useful in cases of suspected anovulation. An absent or impaired response implies an abnormality, primary or secondary, of the pituitary gonadotrophs, and if the situation is irreversible in such cases infertility may be treated with gonadotrophins provided there is biopsy evidence of adequate follicular tissue. ${ }^{10}$ With a normal or exaggerated LH-RH response it is important to carry out a clomiphene stimulation test also. In women with primary ovarian failure the exaggerated response to $\mathrm{LH} / \mathrm{FSH}-\mathrm{RH}$ is confirmed by high $\mathrm{LH}$ levels unaffected by clomiphene. Patients with normal LH/FSH-RH responses may be divided into those with disturbed cyclical gonadotrophin release, who respond to clomiphene, and those with a block in releasing-hormone production, who do not. Infertility in the former group may respond to repeated courses of clomiphene, with or without human chorionic gonadotrophin to induce follicular rupture. In the latter group $\mathrm{LH} / \mathrm{FSH}-\mathrm{RH}$ itself may eventually prove to be an effective and physiological alternative to gonadotrophin therapy.

We thank Dr. W. Bogie of Hoechst for supplies of LH/FSH-RH and Mr. A. Hyden for help with LH assay.

\section{References}

${ }^{1}$ Kastin, A. J., et al., fournal of Clinical Endocrinology and Metabolism, $1972,34,753$.

${ }^{2}$ Mortimer, C. H., et al., British Medical fournal, 1973, 4, 73.

3 Jacobson, A., Marshall, J. R., and Ross, G. T., American fournal of Obstetrics and Gynecology, 1968, 101, 1025.

4 Jacobson, A., et al., American fournal of Obstetrics and Gynecology, 1968, $102,284$.

5 Besser, G. M., et al., British Medical fournal, 1972, 3, 267.

6 Brooks, R. V., Gas Liquid Chromatography of Steroids, p. 147. Cambridge, Cambridge University Press, 1967.

7 Spitz, I. M., et al., New England fournal of Medicine, 1974, 290, 10.

${ }^{8}$ Mecklenburg, R. S., et al., Medicine, 1974, 53, 147.

${ }^{9}$ Marshall, J. C., and Russell Fraser, T., British Medical fournal, 1971, 4, 590.

${ }^{10}$ Sykes, D. W., and Ginsburg, J., American fournal of Obstetrics and Gynecslogy, 1972, 112, 408.

\title{
Evidence for HL-A-linked Genes in "Juvenile" Diabetes Mellitus
}

\author{
A. G. CUDWORTH, J. C. WOODROW
}

British Medical fournal, 1975, 3, 133-135

\section{Summary}

HL-A typing of 150 patients who had developed diabetes mellitus by the age of 30 years showed a significant association with HL-A 8 and $W$ 15. The HL-A genotypes were determined in 17 families in which two or more siblings had this type of diabetes. The zygotic assortment of HL-A haplotypes was found to be significantly disturbed from the expected random pattern, with a reduction in the number of siblings showing no identical haplotypes and an appreciable increase in the number with both haplotypes identical. This appears to be most consistent with the presence of a gene or genes predisposing to this type of diabetes at a locus closely linked to the HL-A chromosomal loci. This locus appears to have a fundamental role in the susceptibility to juvenile diabetes.

\section{Introduction}

Any inquiry into the mechanisms underlying juvenile-onset diabetes mellitus must take into account the role of genetic determination. Analysis of the familial aggregation of the disorder suggests that this is complex and is consistent with polygenic inheritance. ${ }^{1}$ One of the loci involved may be in the HL-A chromosomal region. ${ }^{2-4}$ To throw further light on this we have studied 150 cases of juvenile-onset diabetes together with families containing two or more diabetic siblings. The aim of the family studies was to determine whether within families the

University Department of Medicine, Liverpool L69 3BX

A. G. CUDWORTH, M.D., M.R.C.P., Lecturer in Medicine

J. C. WOODROW, M.D., F.R.C.P., Reader in Medicine pattern of inheritance of HL-A haplotypes is relevant to the development of diabetes.

\section{Patients and Methods}

The 150 patients were attending hospital with insulin-dependent diabetes. In all cases the age at onset was 30 years or less, this cut-off point being selected arbitrarily to achieve reasonable homogeneity. For comparison 68 diabetics whose age at onset ranged from 31 to 80 years were also studied. A control population of 300 was made up of blood donors, members of staff, and students living in the same geographical area. HL-A typing was performed with a modified lymphocytotoxicity technique. ${ }^{5}$

In the juvenile-onset cases detailed family histories were taken, and when one or more siblings with juvenile-onset diabetes were thus ascertained they, together with the parents, were also HL-A typed. The aim was to determine whether in respect of the affected siblings one, both, or neither HL-A haplotypes were identical. Identity of the haplotype is used here to indicate that haplotypes in two siblings not only type the same but are present on identical chromosomes inherited from a parent. By typing the parents it was possible to determine this. When two siblings have a haplotype typing the same it is not possible to be certain that they are identical if one parent is homozygous for this haplotype. When there was uncertainty because one or both parents were dead the family was excluded from the analysis.

\section{Results}

As studies have shown positive associations of juvenile-onset diabetes with HL-A 8 and W $15^{2-4}$ only the data for these particular antigens are given. No definite association with any other HL-A antigen was found. Of the 150 juvenile-onset diabetics $74(49.3 \%)$ were positive for HL-A 8 compared with $93(31.0 \%)$ of the controls; this gives a relative risk ${ }^{6}$ of $2.17\left(\chi^{2}=14.14 ; \mathrm{P}=0.023\right)$. In a report from Copenhagen on 69 diabetics whose age at onset was 30 years or less ${ }^{7}$ the relative risk for this type of diabetes in patients positive for HL-A 8 was $2 \cdot 79$. When the two sets of data are combined the overall risk for 